\title{
Comparative Study of Library and Information Science Curricula in Tertiary Institutions in South-East Nigeria.
}

\author{
${ }^{1}$ Rev'd Obiora Nwosu, ${ }^{2}$ God'sgift Ukoma Eyisi, ${ }^{3}$ Aghauche Esther Ekene \\ ${ }^{I}$ PhD - CLN (Associate Professor) Department of Library and Information Science Nnamdi Azikiwe University, \\ Awka \\ ${ }^{2}$ Lecturer: Department Of Library and Information Science Federal Polytechnic, Oko \\ Anambra State. \\ ${ }^{3}$ Lecturer: Department of Library and Information Science Nnamdi Azikiwe University, Awka.
}

\begin{abstract}
This study was undertaken in order to highlight and compare the curricula of the different Library Schools in the tertiary institutions, South East, Nigeria. This is a descriptive survey, using a checklist (the minimum academic standards provided by the different regulatory bodies - NUC and NBTE). All the ten Library Schools in South-East, Nigeria, were used for the study. The results of the study reveal that there are no uniformity and conformity in the curricula run in the Universities, but there are uniformity in the Polytechnics curricula. In spite of the uniformity \& conformity with its regulatory body's minimum standard, the Polytechnic curriculum is not suitable for registerable status as Librarians to be accorded to its products. The regulatory bodies rely heavily and wholly on professional bodies to provide their different professional and academic programmes standards. The NLA and LRCN are not doing much yet in the area of standardization and harmonization of the curricula so as to train Librarians/Information Scientists of this $21^{s t}$ century.
\end{abstract}

Keywords: Library and Information Science, Curriculum, Tertiary Institutions, Comparative Study and Standards.

\section{Introduction}

This paper is on comparative study of library and information science curricula in tertiary institutions in South-East of Nigeria. The central theme is curricula of the Professionalization of Library and Information Science in Nigerian tertiary institutions. Librarianship has attained all the attributes of a profession. It has its theoretical base, intellectual content, well structured formal education programmes, ethics, bill of right and association that champions its cause. A formal education programme cannot do without a well articulated curriculum. According to Coles (2003), curriculum is the embodiment of a programme of learning and includes philosophy, content, approach and assessment. Smith (2000) sees curriculum as "all the learning which is planned and guided by the school...." Curriculum is, therefore, a body of knowledge to be transmitted to achieve certain ends in students (product). Curriculum is heavily dependent on the setting of behavioural objectives. 'Curriculum is not simply a set of plans to be implemented, but rather is constituted through an active process in which planning, acting and evaluating are all reciprocally related and integrated into the process' (Grundy 1987:115). At its centre is praxis: informed, committed action.

Curriculum as practice cannot be changed substantially without adequate attention to professional changing trend. In 2007, the National Association of Library and Information Science Educators (NALISE), held a National conference. The concern of the conference was on harmonizing and standardizing of the library and information science curricula for all Nigerian library and information science curricula for all the Nigerian library schools. Lawal (2009) concern was on how library educators were tackling the problem of local relevance in their programmes. He endorsed the National Universities Commission (NUC) minimum academic standards for library and information science as a quality assurance tool capable of helping library schools prepare professionals who are adequately trained to be able to support the library's mission, goals, and objectives. The curriculum, the NUC adopted and approved as the minimum academic standard for library and information science was articulated in 1995 by the Nigerian Library Association Education Committee. Information and Communication Technology that has currently revolutionalised the trend in librarianship was not in vogue as at then. The curriculum articulated in 1995 is not only antiquated but does not provide for the current professional skills and techniques needed for this $21^{\text {st }}$ century librarianship. Nwosu (2009) recommended an upgrade of the curricula to reflect the ever dynamic information super-highway. Diso (2009) and Umar (2009) equally picked holes with the NUC minimum academic standards in Library and information science. Nwosu (2008) made it clear to the NLA that the Academic programme provided by the National Board for Technical Education (NBTE) for Diploma programme in Library and Information Science in Nigerian Polytechnics is not adequate too. 


\section{The Problem}

The library educators at their 2007 National Conference succeeded only in brainstorming without effecting the most needed curriculum harmonization and standardization. The NUC and NBTE provided the minimum academic standard (curriculum). Library schools are expected to improve and enlarge it to meet the profession's demands for the $21^{\text {st }}$ century. Greater majority of the present library educators were not trained in ICT and computer applications to the library. Too, those who designed the academic programme (curriculum), which both the NUC and NBTE adopted were not ICT compliant. With their non-exposure or low exposure to ICT, any curricula review by them, will most likely be deficient in computer and ICT areas which are now in vogue in library and information science. It is, therefore, most pertinent, at this time, where there are many contenders to relieve the librarians of their esteemed job, that the curricula should be critically looked at, with the view of coming out with excellent curricula for the Nigerian University and Polytechnic Library Schools. The concern of this study is the comparative study of the library and information curricula run by library schools in the South-East of Nigeria.

\section{Research Method}

This is a descriptive survey. The minimum academic standards (curricula) articulated and provided by the different regulatory bodies, NUC and NBTE, for Library and Information Science programmes, were used as the checklists. There are ten tertiary institutions in the South-East of Nigeria that offer Library and Information Science. They are: University of Nigeria, Nsukka; Nnamdi Azikiwe University, Awka; Abia State University, Uturu; Imo State University, Owerri; Enugu State University of Technology, Enugu; Madonna University, Okija; Federal Polytechnic, Nekede; Federal Polytechnic, Oko; Federal College of Education (Technical), Umunze and Enugu State College of Education (Technical), Enugu. In all, there are two Federal Universities (UNN and NAU), three State Universities (ABSU, IMSU and ESUT), one Private University (Madonna), two Federal Polytechnics, one Federal and one State Colleges of Education (Technical) that offer Library and Information Science. The respective Library and Information Science curricula run by the ten library schools were critically looked into, in relation to the respective minimum standards.

\section{Result and Discussion}

All the six universities offer first degree programmes in Library and Information Science. The two Federal Polytechnics offer both National Diploma and Higher National Diploma in Library and Information Science. The two Colleges of Education are affiliated to Nnamdi Azikiwe University, Awka and thus, they offer only first degree programmes in Library and Information Science. With the exception of ESUT, all the other five universities offer postgraduate programmes, up to doctorate degree, in Library and Information Science. NUC has not yet come out with the minimum academic standards for postgraduate programmes in Library and Information Science. What are on ground are the different curricula designed by the respective library schools running postgraduate programmes.

\section{The NUC Minimum Academic Standard (Curriculum)}

The NUC in the minimum academic standards for Library and information science categorized the courses into: core/compulsory courses, cognate courses, restricted electives; unrestricted electives, concurrent courses and pre-requisite course. The core/compulsory courses, according to NUC (1995) are central to the degree programme in view and are normally offered by the Department offering the degree. The cognate courses are prescribed courses from related fields which are required for an understanding and appreciation of the student's major field. The restricted electives are optional courses taken from defined areas from which students are to choose specific courses and the courses are normally offered by other departments within the same Faculty. The unrestricted electives are courses which are opted for by a student in his own interest and are normally offered from outside the Faculty but has to be determined by the Faculty. The NUC gave each library school the opportunity to use its jurisdiction to define its own restricted, unrestricted and concurrent electives. 
Table I: The core/compulsory courses provided by NUC and the extent of compliance by the different

library schools.

\begin{tabular}{|c|c|c|c|c|c|c|c|}
\hline \multirow[t]{2}{*}{$\mathbf{S} / \mathbf{n}$} & \multirow{2}{*}{ Core/compulsory courses } & \multicolumn{6}{|c|}{ Library Schools Compliance } \\
\hline & & UNN & NAU & ABSU & IMSU & ESUT & Madonna \\
\hline 1 & Libraries \& Society & $\square$ & $\square$ & $\square$ & $\square$ & $\square$ & - \\
\hline 2 & $\begin{array}{l}\text { Intro. To Lib. \& Information } \\
\text { Resources }\end{array}$ & $\square$ & $\square$ & $\square$ & - & $\square$ & - \\
\hline 3 & Intro. To Bibliography & $\square$ & $\square$ & $\square$ & $\square$ & $\square$ & $\square$ \\
\hline 4 & $\begin{array}{l}\text { Organization of Knowledge } \\
\text { I }\end{array}$ & $\square$ & $\square$ & $\square$ & $\square$ & $\square$ & $\square$ \\
\hline 5 & $\begin{array}{l}\text { Oral Tradition \& Cultural } \\
\text { Literature }\end{array}$ & $\square$ & $\square$ & $\square$ & $\square$ & $\square$ & - \\
\hline 6 & $\begin{array}{l}\text { Book Production \& } \\
\text { Publishing }\end{array}$ & $\square$ & $\square$ & $\square$ & $\square$ & $\square$ & $\square$ \\
\hline 7 & $\begin{array}{l}\text { Organization of Knowledge } \\
\text { II }\end{array}$ & $\square$ & $\square$ & $\square$ & $\square$ & $\square$ & $\square$ \\
\hline 8 & Collection Development & $\square$ & $\square$ & $\square$ & $\square$ & $\square$ & $\square$ \\
\hline 9 & $\begin{array}{l}\text { Reference \& Information } \\
\text { Services }\end{array}$ & $\square$ & $\square$ & $\square$ & $\square$ & $\square$ & $\square$ \\
\hline 10 & $\begin{array}{l}\text { Technical Services in Lib. \& } \\
\text { Info. Centres }\end{array}$ & $\square$ & $\square$ & $\square$ & $\square$ & $\square$ & $\square$ \\
\hline 11 & $\begin{array}{l}\text { Intro. To Information } \\
\text { Science }\end{array}$ & $\square$ & $\square$ & $\square$ & $\square$ & $\square$ & $\square$ \\
\hline 12 & Research Method & $\square$ & $\square$ & $\square$ & $\square$ & $\square$ & $\square$ \\
\hline 13 & Research Project & $\square$ & $\square$ & $\square$ & $\square$ & $\square$ & $\square$ \\
\hline 14 & Field Experience (SIWES) & $\square$ & $\square$ & $\square$ & $\square$ & $\square$ & $\square$ \\
\hline 15 & Indexing \& Abstracting & $\square$ & $\square$ & $\square$ & $\square$ & $\square$ & $\square$ \\
\hline 16 & $\begin{array}{l}\text { Automation in Libraries \& } \\
\text { Information Centres }\end{array}$ & - & $\square$ & $\square$ & $\square$ & $\square$ & $\square$ \\
\hline 17 & $\begin{array}{l}\text { Libraries \& Information in } \\
\text { Rural Communities }\end{array}$ & - & $\square$ & $\square$ & - & $\square$ & $\square$ \\
\hline & & $88.24 \%$ & $100 \%$ & $100 \%$ & $88.23 \%$ & $100 \%$ & $82.35 \%$ \\
\hline
\end{tabular}

Table I shows the extent of compliance to the core courses by the six university library schools in the South East, Nigeria. NAU, ABSU and ESUT library schools had 100\% compliance to the NUC's core courses respectively. UNN, IMSU and Madonna library schools had $88.24 \%, 88.23 \%$ and $82.35 \%$ compliance to the NUC's compulsory courses. The two Colleges of Education that are affiliated to NAU offer exactly the courses offered at NAU library school.S

There is always need to comply totally to the compulsory courses in a minimum academic standard approved by a regulatory body. The non-core courses can be compromised but not the core ones.

With the current emerging and dynamic trend in librarianship, the core courses as provided in the NUC's minimum standard are no longer core enough in this $21^{\text {st }}$ century library and information science profession. At the present time, any library school that teaches only the dated NUC minimum academic curriculum is but a traditional library school of the past century. The current NUC minimum academic standard curriculum for librarianship needs to be reviewed and updated, if our profession here in Nigeria wants to keep pace with the emerging trends. We cannot afford to be irrelevant in this $21^{\text {st }}$ century. We must catch up, meet the current professional demand and be more than equal to the task.

\section{NUC Restricted Electives}

As explained by the NUC, restricted electives are courses outside the Department of Library and Information Science but offered by other Departments in the same Faculty. Although that is the explanation but their list of the restricted courses are all resident in the Department of Library and Information Science. 
Table II: The NUC Restricted Electives and the extent of compliance bythe library schools.

\begin{tabular}{|c|c|c|c|c|c|c|c|}
\hline \multirow[t]{2}{*}{$\mathbf{S} / \mathbf{n}$} & \multirow[t]{2}{*}{ Restricted Electives } & \multicolumn{6}{|c|}{ Library Schools Compliance } \\
\hline & & UNN & NAU & ABSU & IMSU & ESUT & Madonna \\
\hline 1 & $\begin{array}{l}\text { History of libraries \& Info } \\
\text { centres in Nigeria }\end{array}$ & $\square$ & - & $\square$ & - & $\square$ & $\square$ \\
\hline 2 & $\begin{array}{l}\text { Foundations of libraries \& } \\
\text { information science }\end{array}$ & - & $\square$ & $\square$ & $\square$ & $\square$ & $\square$ \\
\hline 3 & Library \& Info Centre visits & $\square$ & $\square$ & $\square$ & - & $\square$ & - \\
\hline 4 & $\begin{array}{l}\text { Literature \& libraries services to } \\
\text { children \& Adolescent }\end{array}$ & $\square$ & $\square$ & - & $\square$ & $\square$ & $\square$ \\
\hline 5 & Serials management & $\square$ & $\square$ & - & - & $\square$ & - \\
\hline 6 & Information users & $\square$ & $\square$ & $\square$ & - & - & $\square$ \\
\hline 7 & Intro to Audio-visual Resources & $\square$ & $\square$ & $\square$ & $\square$ & $\square$ & $\square$ \\
\hline 8 & $\begin{array}{l}\text { Public libraries \& information } \\
\text { centres }\end{array}$ & - & $\square$ & $\square$ & $\square$ & $\square$ & - \\
\hline 9 & $\begin{array}{l}\text { School libraries \& media } \\
\text { Resource centres }\end{array}$ & $\square$ & $\square$ & - & $\square$ & $\square$ & $\square$ \\
\hline 10 & Academic \& Resource Libraries & $\square$ & $\square$ & $\square$ & $\square$ & $\square$ & - \\
\hline 11 & $\begin{array}{l}\text { National libraries \& information } \\
\text { centres }\end{array}$ & $\square$ & $\square$ & $\square$ & - & $\square$ & $\square$ \\
\hline 12 & $\begin{array}{l}\text { Special libraries \& information } \\
\text { centres }\end{array}$ & - & $\square$ & $\square$ & $\square$ & $\square$ & - \\
\hline 13 & $\begin{array}{l}\text { Management of libraries \& } \\
\text { information centres }\end{array}$ & $\square$ & $\square$ & $\square$ & $\square$ & $\square$ & - \\
\hline 14 & $\begin{array}{l}\text { Preservation \& conservation of } \\
\text { libraries materials }\end{array}$ & $\square$ & $\square$ & $\square$ & - & $\square$ & $\square$ \\
\hline 15 & Government publications & $\square$ & $\square$ & - & - & $\square$ & $\square$ \\
\hline 16 & $\begin{array}{l}\text { Archives Administration \& } \\
\text { Records management }\end{array}$ & $\square$ & $\square$ & $\square$ & - & - & $\square$ \\
\hline 17 & Publishing and book trade & - & $\square$ & $\square$ & - & - & $\square$ \\
\hline 18 & $\begin{array}{l}\text { Bibliography \& Literature of } \\
\text { social science }\end{array}$ & $\square$ & $\square$ & $\square$ & $\square$ & $\square$ & $\square$ \\
\hline 19 & $\begin{array}{l}\text { Bibliography \& Literature of } \\
\text { Humanities }\end{array}$ & - & $\square$ & $\square$ & $\square$ & - & - \\
\hline 20 & $\begin{array}{l}\text { Bibliography \& Literature of } \\
\text { Science \& Technology }\end{array}$ & $\square$ & $\square$ & $\square$ & $\square$ & $\square$ & $\square$ \\
\hline & & $75 \%$ & $95 \%$ & $80 \%$ & $55 \%$ & $80 \%$ & $65 \%$ \\
\hline
\end{tabular}

Table II shows the extent of compliance to the restricted electives by the library schools. Out of the 20 NUC restricted electives, UNN, NAU, ABSU, IMSU, ESUT and Madonna offer 15(75\%), 19(95\%), 16(80\%), $11(55 \%), 16(80 \%)$ and $13(65 \%)$ respectively. The restricted electives are specifically referred to as required courses by ABSU. This is what the premier library school in Nigeria at the University of Ibadan calls them. All the required courses must be offered and passed by the students. UNN, NAU and IMSU, offer either 'History of libraries and information centres' or 'foundations of library and information science'. The two courses are related. What they did was to incorporate the topics that are not included in the one they opted for.

The approved restricted electives did not include ICT, and computer related courses which have now taken over every aspect of our professional practice and operations. There is an urgent need, therefore, to include all the necessary and relevant ICT and computer related courses in the curriculum. They are means to our professional ends in this $21^{\text {st }}$ century.

\section{Cognate Courses and Unrestricted Electives}

The cognate courses are the subject areas. Librarianship demands subject area background. This helps in giving specialized information services in a particular discipline. The subject area, at present, is not reflected in the certificate awarded. They are for now taken as subject minors. Students are to take six (6) to nine (9) credit units in other academic disciplines such as Arts, Social Sciences, Science, and Humanities each academic session up to the 400 level. This is complied with by all the library schools in the South-East Nigeria.

For the unrestricted electives, students are supposed to take two credit units from any academic programme in the university only at the 100 level. Only Unizik has complied to this. 
Efforts By some of the Library Schools to improve on the Minimum Academic Standard/Curriculum for the First Degree.

In a bid to augment and improve on the NUC minimum curriculum for the first degree library and information science programme, some of the library schools added some new courses.

Table III: Added courses to the NUC minimum standard by the different library schools.

\begin{tabular}{|c|c|c|c|c|c|c|c|}
\hline \multirow[t]{2}{*}{$\mathbf{S} / \mathbf{n}$} & \multirow[t]{2}{*}{ Added courses } & \multicolumn{6}{|c|}{ Library Schools } \\
\hline & & UNN & NAU & ABSU & IMSU & ESUT & $\begin{array}{l}\text { Madonn } \\
\text { a }\end{array}$ \\
\hline 1 & $\begin{array}{l}\text { Computers \& data/information } \\
\text { Processing }\end{array}$ & $\square$ & $\square$ & - & - & $\square$ & - \\
\hline 2 & Introduction to ICT and library & $\square$ & $\square$ & - & $\square$ & $\square$ & - \\
\hline 3 & Economics \& marketing of information & $\square$ & $\square$ & - & - & - & - \\
\hline 4 & $\begin{array}{l}\text { International \& comparative } \\
\text { librarianship }\end{array}$ & - & - & $\square$ & $\square$ & - & $\square$ \\
\hline 5 & Issues \& themes on librarianship & - & - & $\square$ & $\square$ & - & - \\
\hline 6 & Cataloguing with MARC21 & - & $\square$ & - & $\square$ & - & - \\
\hline 7 & Information storage \& Retrieval & - & - & - & $\square$ & - & - \\
\hline 8 & $\begin{array}{l}\text { Inter-library cooperation/ information } \\
\text { systems \& information network }\end{array}$ & $\square$ & - & $\square$ & - & - & $\square$ \\
\hline 9 & Management information systems & - & $\square$ & - & - & - & $\square$ \\
\hline 10 & Database design \& management & - & $\square$ & - & - & - & - \\
\hline 11 & $\begin{array}{l}\text { Information technologies \& internet } \\
\text { connectivity }\end{array}$ & - & $\square$ & - & - & - & - \\
\hline 12 & $\begin{array}{l}\text { Information structure and system I - } \\
\text { IV }\end{array}$ & - & - & $\square$ & - & - & $\square$ \\
\hline 13 & Library \& information service policy & $\square$ & - & - & - & - & - \\
\hline 14 & Library building & - & - & - & $\square$ & - & $\square$ \\
\hline 15 & Literature of African Studies & $\square$ & - & - & - & - & - \\
\hline 16 & Sociology of librarianship & - & - & $\square$ & - & - & - \\
\hline 17 & Copyright and legal issues in L.I.S & - & - & - & - & - & $\square$ \\
\hline 18 & $\begin{array}{l}\text { Entrepreneurship in library \& } \\
\text { information science. }\end{array}$ & - & - & - & - & - & $\square$ \\
\hline 19 & Internet and virtual libraries & - & - & - & - & - & $\square$ \\
\hline 20 & $\begin{array}{l}\text { Practical lab. Work (I-IV)/Library } \\
\text { Routine }\end{array}$ & - & - & - & $\square$ & - & - \\
\hline & & $30 \%$ & $35 \%$ & $25 \%$ & $35 \%$ & $10 \%$ & $40 \%$ \\
\hline
\end{tabular}

Table II above shows indiscriminate addition of courses, probably due to idiosyncrasy and/or areas of interest of the operators of the different library schools. The above added courses are not among the courses listed in the NUC minimum standard. There is an uncoordinated and unilateral addition of courses by the different library schools. Each library school designed and added few courses as thought relevant. Even where the course titles are the same in another library schools, the course contents are different.

Out of the identified 20 added courses, UNN, NAU, ABSU, IMSU, ESUT and Madonna University, added $6(30 \%), 7(35 \%), 5(25 \%), 7(35 \%), 2(10 \%)$, and 8(40\%) respectively. There is every need to streamline these courses and determine the course contents of the very relevant ones. The few ICT and computer related courses lack depth and practical provisions that will help get the trainees (students) grounded and efficient.

There are very important and most relevant courses that should be and must be added to the NUC minimum standard if our budding librarians are to be relevant in this present century. There must be theoretical and practical oriented courses in the following courses:

- Digital Library Development and Management

- Virtual Library Development and Management

- Information Literacy

- MARC21/Resource Description and Access (RDA)

- E-library and e-resources management

- Social Media and Library

- Information Retrieval and Search Engines

- Metadata Development

- Library Software Development and Application

- Webmetrics

- etc 
The above list is not exhaustive. Both the NLA and the Librarians Registration Council of Nigeria (LRCN) should sit down with authorities (Professors) in Nigerian Library Schools to come out with sound curriculum for Library and Information Science programmes. The NUC depends on what professional bodies submit to her for approval and implementation. It is proper at this juncture to inform the NLA that the library and information science curriculum which the NUC approved as the minimum academic standard for first degree programme, was designed by the NLA Education committee. The NUC did not add or delete anything from it.

\section{Curriculum and Modules Specifications for National and Higher National Diploma (ND \& HND) in Library and Information Science in Nigerian Polytechnics.}

The regulatory body for the Polytechnic education in Nigeria, the NBTE, has a well thought out curricula and modules specifications for both the ND and HND programmes in Library and Information Science. The NBTE published the first ND and HND curricula in library science in 1989 (Appendix I), which the two Federal Polytechnics in the South-East of Nigeria started to implement in 1990. None of the two Polytechnics made any additional input to the courses provided by the NBTE. In 2002, the NBTE published a reviewed curriculum for only the ND-Library and Information Science Programme. They simply added the following courses to the existing ones: (1) Sociology of Library and Information Science; (2) Basics of computer operating systems; (3) Research methods; (4) Elements of Library automation; (5) Project; (6) Introduction to internet and virtual library. Then in 'Compilation of Bibliography' (which was the only project in ND then), the Board expanded it to read 'Compilation of Bibliography, Indexes and Abstracts'. It is only the Federal Polytechnic, Oko, that has started to implement the revised ND curriculum. Since the HND curriculum has not been revised, the two Polytechnics are still using the published 1989 minimum academic standard. The Polytechnic L.I.S curricula are also lacking in the key computer and ICT related courses.

The Polytechnic Library and Information Science Programmes (ND \& HND) still do not have any subject background, which is a requirement for registration with the Librarians Registration Council of Nigeria. The National Body, the NLA and Librarians Registration Council of Nigeria have to rectify this problem, now or never, if they want Polytechnic Library education to be worth running.

\section{Curricula for Postgraduate Programmes in Library and Information Science in Universities, South-East,} Nigeria.

The NUC has not come out with any curriculum for postgraduate programmes in library and information science. Each library school formulated her own peculiar curriculum for postgraduate programmes. There is, therefore, no standard curriculum that was used as the checklist for comparism of the different curricula run by the different library schools.

A critical look at all the postgraduate curricula run by UNN, NAU, ABSU, IMSU and Madonna University, revealed that no two of the universities have identical curricula. There is, therefore, no uniformity in the postgraduate curricula adopted and implemented by the library schools.

Of great concern and source of deep worry is that the content of courses in almost all the library schools are shallow. Some of the courses basically have no content. Not being immodest, in ABSU, LSM 772: Bibliometrics (4 units), has as its course content: "The course will be taught on a combination of lectures, seminars and tutorials. Detailed study of types, forms and patterns of bibliometrics; practical sessions on bibliometric studies should be included on the course content". The above course content is empty. The same course (LIS 724: Bibliometrics) at NAU, the curriculum content reads as follows:

Evolution and definition of Bibliometrics as a sub-discipline; relationship to information science; qualification of the information problem; dispersion of subject literature (Bradford - Zigf distributions); citation patterns, authorship patterns (Lotka's Law); obsolescence rates, science indicators and structure of disciplines and subfields.

This is much better compared to that of ABSU, but is not altogether all that are required to be learnt in Bibliometrics.

Majority of the professional bodies register their members as professionals only when they have obtained masters degree. That being the case, masters degree programme in library and information science should have coverage and range of courses. In some library schools, some postgraduate students are admitted without any background knowledge in library and information science, as they studied other disciplines. The postgraduate programmes should have students grounded in every aspect of librarianship. With the aforesaid, it is only proper to design postgraduate programmes in library and information science to cover all aspects of the profession. This is not so in the respective PG curricula of ABSU, IMSU, UNN, and Madonna University library schools. They have very limited number of courses and still some of them are irrelevant. PG programmes are research oriented, thus the research and statistical courses should be elaborated. UNN, NAU and Madonna 
library schools have relatively well articulated research method courses but that of ABSU leaves much to be desired.

The NLA and LRCN are challenged to rise up and design for the NUC standard academic curricula for postgraduate programmes in library and information science. The PG curricula situation on ground now is ugly and disturbing. This informed why some PG students abandon their PG programmes in a library schools with well thought out and elaborate curricula, for other library schools with shallow curriculum content. This has to be addressed only by the LRCN coming up with standardized curricula for postgraduate programmes.

\section{Recommendations and Conclusion}

There are minimum academic standards in library and information science for diploma (ND \& HND) and degree programmes in Nigerian Polytechnics and Universities respectively. The different minimum standards by NBTE and NUC clearly spelt out the curricula contents. There are no standardized curriculum for the postgraduate programmes in library and information science. Each library school articulated and designed her curriculum. This is not acceptable in curriculum designing for any established profession.

There are expert curriculum designers. The NBTE utilizes expert curriculum designers, while the NUC do not really bother to. Curriculum should be stated in behavioural and pedagogical terms, with the overall goal, general and specific objectives well spelt out for every course. The learning outcome for every topic in a particular course is always specified. This leaves no one in doubt what are expected to be taught, learnt and evaluated (Smith 2000). The aforesaid are taken care of by only the NBTE. The first degree curriculum in library and information science by NUC, therefore, is deficient in behavioural objectives.

Library and information science is the most dynamic academic discipline because it is highly related to the super dynamic and ever evolving ICT that has overtaken the world. Our profession should be regularly reviewing the curricula so as to keep pace and trend with every new demand on the professional practices and services. Presently, both the NBTE and NUC minimum academic standards for library and information science are not good enough to produce librarians for this present $21^{\text {st }}$ century professional skills' demand.

Even with the uniformity and conformity with its regulatory body's minimum standards, the Polytechnic curriculum is yet not suitable enough for registerable status as librarians to be accorded to its products. The regulatory bodies rely heavily and wholly on professional bodies to provide their different professional and academic programmes standards. The NLA and LRCN are not doing much yet in the area of standardization and harmonization of the curricula so as to train librarians and information scientists of this $21^{\text {st }}$ century. They have to sit up and do something now or the profession will be irrelevant in the professional training and professional services in Nigeria. The bastardization and slaughter of the postgraduate programmes in library and information science at the altar of library and/or University autonomy has to be addressed by LRCN. There are no uniformity let alone conformity in their collective curricula. No single PG curriculum in the studied library schools is the same with any other. This has to be addressed by our professional body, NLA. One of the major attributes of any profession is a well structured intellectual content in a formal tertiary education institution.

\section{References}

[1] Coles,C.(2003).Thedevelopmentofacurriculumforspinalsurgeons.http://www.qualityresearchinternational.com/glosary/curriculum.ht $\underline{\mathrm{m}}$.

[2] Diso, Lukeman (2009). A perspective on standardization of L.I.S curricula in Nigeria. In: Chidi Nwosu and Okee Okoro (2009) eds. Standards for LIS programmes in Nigerian Universities, Owerri: Kosoko Press. 76-85.

[3] Grund, S. (1987). Curriculum: product or praxis? Lewes: Falmer Press.

[4] Kelly, A. V. (1999). The curriculum. Theory and Practice 4e. London: Paul Chapman.

[5] Lawal Olat O. (2009). Standards for Library and Information Science Programmes in Nigerian Universities. In: Chidi Nwosu and Okee Okoro (2009) eds. Standards for Library and Information Science Programmes in Nigerian Universities, Owerri: Kosoko Press: 1-17.

[6] National Board Technical Education (1990). National Diploma and HigherNational Diploma in Library Science. Kaduna: NBTE.

[7] NBTE (2002). National Diploma (ND) in Library and Information Science. Kaduna: NBTE.

[8] National University Commission (1995). Minimum standard for first degree programme in Libraryand Information Science. Abuja: NUC.

[9] Nwosu, Obiora Chukwuma (2008). Education and Training for Library and Information Science ofthe $21^{\text {st }}$ century in Nigerian Polytechnics. In: Libraries without Borders: Globalization of Library and Information Services, Nigerian Library Association. Abuja: HEBN Publishers.

[10] Nwosu, Obiora (2009). Harmonization and Standardization of Library and Information Science curricula in Nigerian University Library Schools. In: Chidi Nwosu and Okee Okoro (2009) eds. Standards for LIS programme inNigerianUniversities.Owerri: Kosoko Press. $66-75$.

[11] Smith, M. K. (2000). 'Curriculum theory and practice'. The encyclopedia of informal education, www.infed.org/biblio/b-curric.htm $(3 / 23 / 2012)$.

[12] Umar, Ibrahim (2009). Harmonization and specification of instructional facilities in L.I.S programmes in Nigeria. In: Chidi Nwosu and Okee Okoro (2009) eds. Standards for L.I.S programme in Nigerian Universities. Owerri: Kosoko Press. 86 - 102. 


\section{APPENDIX I \\ National Board For Technical Education \\ Table Of Contents}

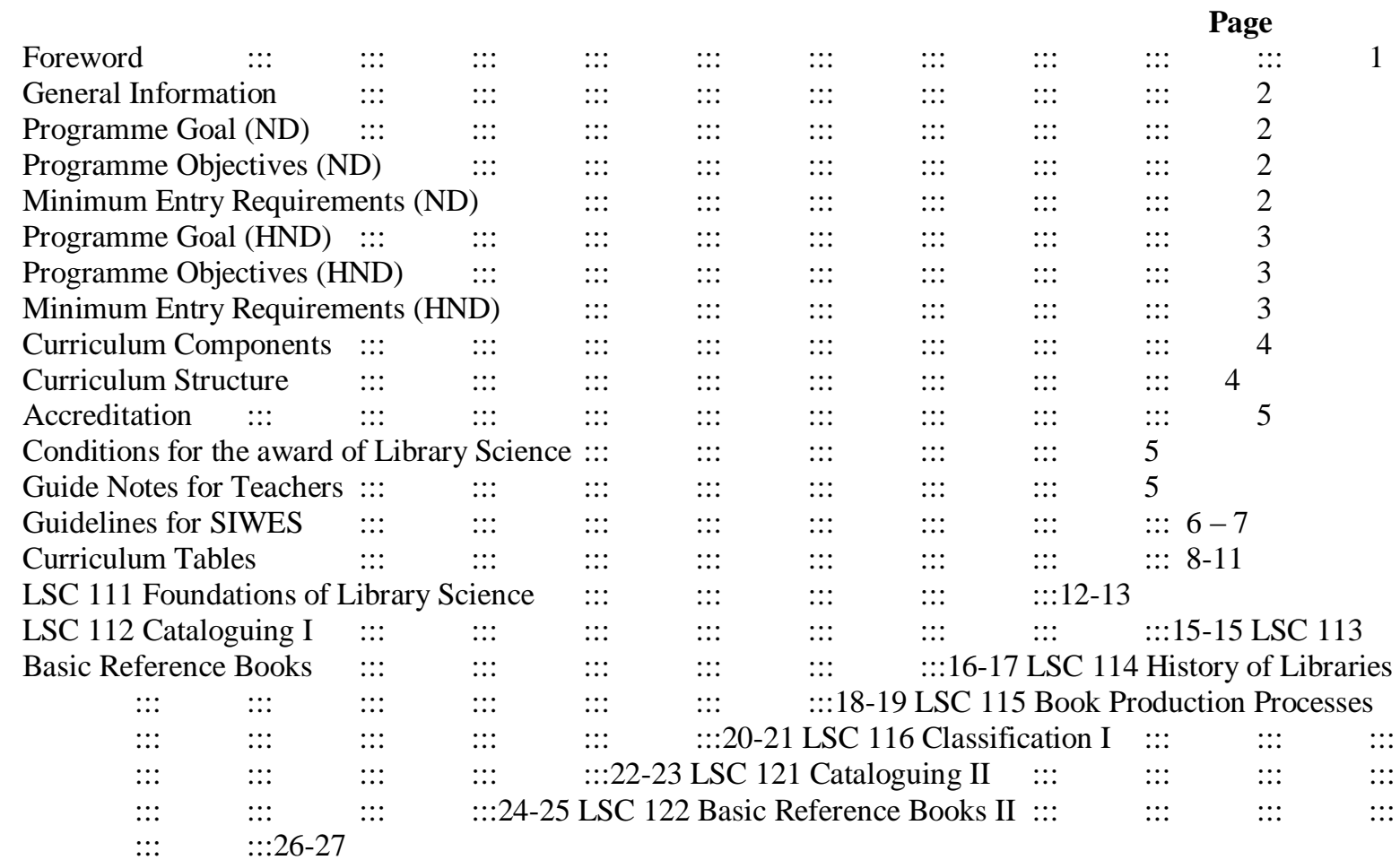

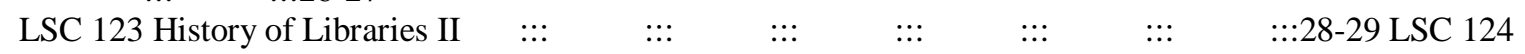

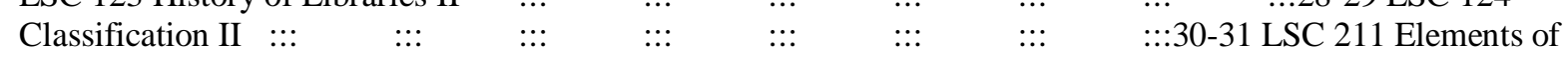

Library Administration $\quad::: \quad::: \quad::: \quad:: 32-33$ LSC 212 Cataloguing and Classification I $\quad:::$ $\because:: \quad::: \quad::: 34-35$ LSC 213 Compilation of Bibliography (Project) I $\quad$ ::: $\quad:::$ $::: \quad::: 36-37$ LSC 214 Elements of Reprography I $\quad$ ::: $\quad::: \quad$ ::: $\quad::: \quad$ :::

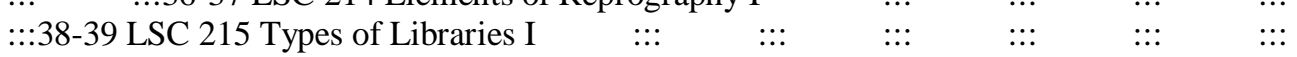

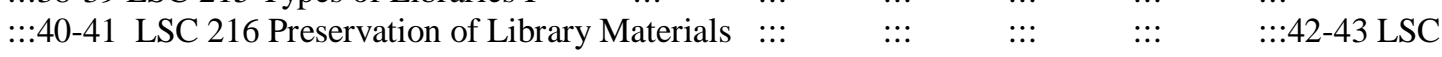
217 Provision of Library Materials $::: \quad$ :: $\quad:: \% \quad::: \quad::: 44-45$

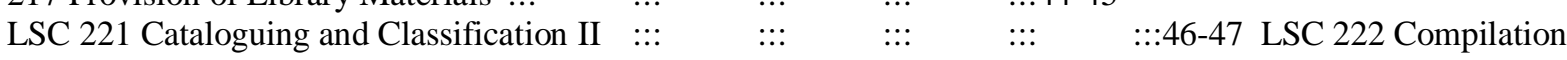
of Bibliography (Project) II $\quad::: \quad:: 0 \quad::: \quad::: 48-49$ LSC 223 Types of Libraries II $\because: \quad \quad::: \quad:: \quad::: \quad::: \quad:: 50-51$ LSC 224 Audio-Visual Equipment, Operation and Materials Production 52-53 LSC 311 Introduction to Information Science

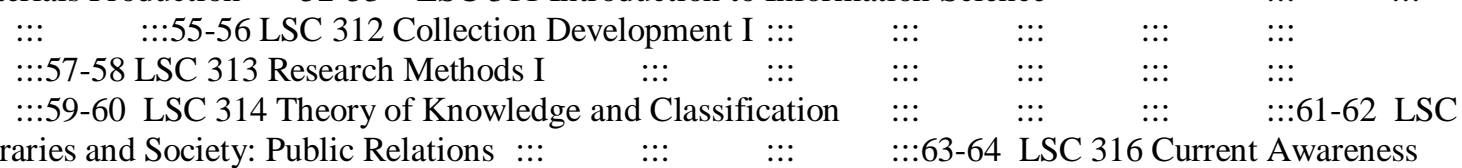

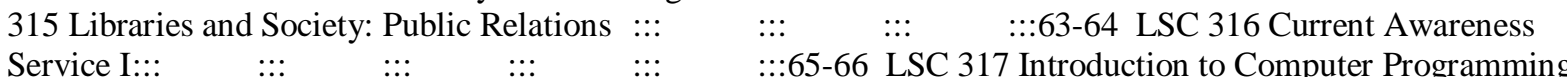

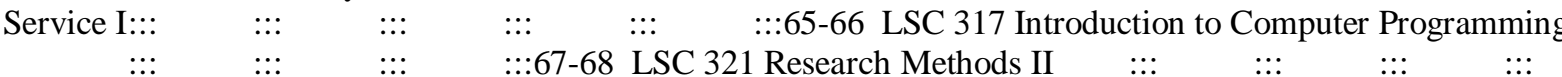
$::: \quad:::: 699-70$ LSC 322 Advanced Cataloguing and Classification I ::: $:::$ :::71-72 LSC 323 Children and School Libraries $\quad::: \quad$ :: $\quad::: \quad::: \quad::: 73-74$ LSC

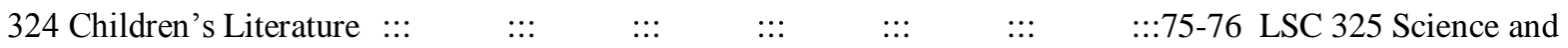
Technology Information Sources and Services $\quad$ :::77-79 LSC 326 Oral Archives $\quad::: \quad$ ::: $\quad::: \quad$

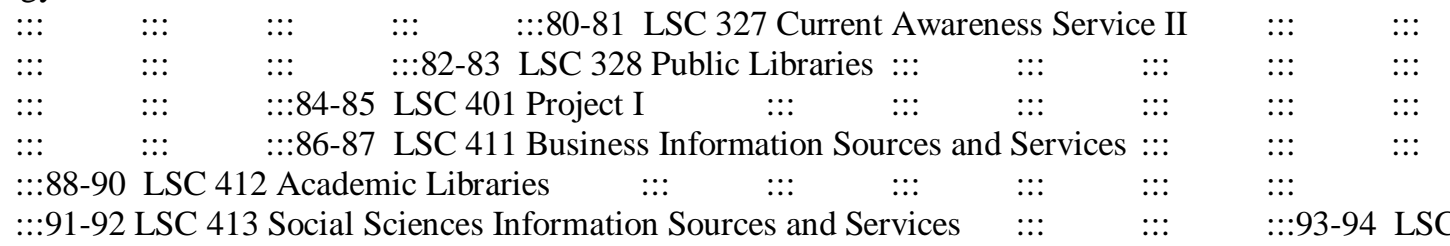
414 Humanities Information Sources and Services $\quad::: \quad:: \quad \quad:: 995-96$ LSC 415 Archives and Records Management $:: \% \quad::$ :: $::$ :::97-98 LSC 416 Advanced Cataloguing and Classification II $::: \quad::: \quad::: 99-100$

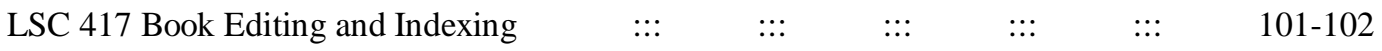


LSC 418 Collection Development $\quad:: \quad \quad:: \quad \quad:: \quad \quad:: \quad \quad:: * \quad$ 103-104 LSC 402 Project II

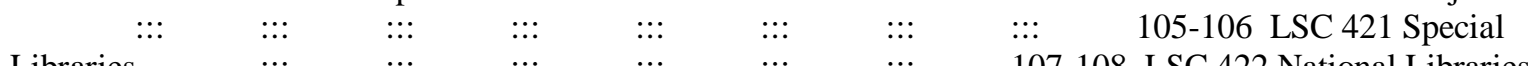

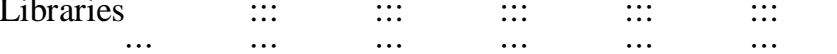

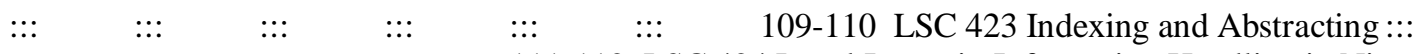

$:: \quad::: \quad:: \quad$ :: $\quad$ 111-112 LSC 424 Legal Issues in Information Handling in Nigeria ::: 113-114 LSC 425 International and Comparative Librarianship $\quad$ :: $\quad::$ :

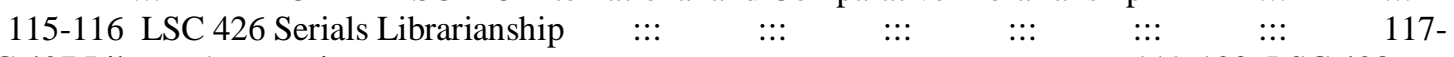

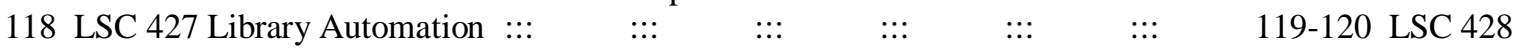

Management Information System $\quad:: \quad \quad:: \quad::: \quad:: \quad$ 121-122 Minimum Tools and

Equipment for National Diploma Programme $::::::: \quad 123$

$\begin{array}{ccccc}\text { Training Library } & ::: & ::: & ::: & :::\end{array}$

Visual Equipment $\quad::: \quad::: \quad::: \quad$ :

Equipment for HND Programme $\quad::: \quad::$ $::: \quad:: \quad::: \quad 126-127$

123 Cataloguing and Classification Laboratory :::

$\because:: \because: \quad:: \% \quad::: \quad 123$ Audio $\because: \quad:: \% \quad$ :: 124 Minimum Tools and 125 List of Critique Workshop Participants ::: 